\title{
Capital adequacy of the banking industry in Indonesia
}

\author{
Sri Murtiyanti ${ }^{1}$, Noer Azam Achsani ${ }^{2}$, Dedi Budiman Hakim ${ }^{3}$ \\ 1,2,3 Graduate School of Management and Business Bogor Agricultural University, Indonesia \\ e-mail: tantiben@gmail.com
}

Article Info

Article history:

Received : 5 July 2015

Accepted : 3 August 2015

Published: 1 October 2015

Keywords:

credit risk, profitability and capital adequacy ratio

JEL Classification:

G21, G24, G29

DOI:

http://dx.doi.org/10.20885/ejem vol7.iss2.art1

\begin{abstract}
This study analyzes the relationship between credit risk and profitability on the capital adequacy ratio (CAR) of commercial banks in Indonesia. The empirical model result shows that credit risk and profitability performance altogether significantly influence the capital adequacy ratio (CAR). Partially, the variables that significantly influence the CAR are the characteristics and complexity of the bank group. This study also suggests that the pace towards the long-term balance is, in general, less than one year. Capital ratio in the banking industry is $8 \%$, indicating the bank has set aside to anticipate the impact of external factors as well as to comply with Bank Indonesia Regulation Number 15/12/PBI/2013.
\end{abstract}

\begin{abstract}
Abstrak
Penelitian ini menganalisis hubungan antara risiko kredit dan profitabilitas pada rasio kecukupan modal bank umum di Indonesia. Hasil dari model empiris menunjukkan bahwa risiko kredit dan kinerja rentabilitas secara bersama-sama berpengaruh signifikan terhadap kecukupan modal (CAR). Secara parsial, variable yang berpengaruh signifikan terhadap CAR adalah karakteristik dan kompleksitas kelompok bank. Penelitian ini juga menunjukkan bahwa kecepatan menuju keseimbangan jangka panjang secara umum kurang adalah dari satu tahun. Rasio modal industri perbankan adalah $8 \%$, menunjukkan perbankan telah menyiapkan modal untuk mengantisipasi dampak faktor-faktor eksternal serta untuk mematuhi Peraturan Bank Indonesia Nomor 15/12/PBI/2013.
\end{abstract}

\section{Introduction}

In modern finance, bank has an important role in the process of financial intermediation (Fungáčová and Poghosyan, 2014). Bank, as an intermediary institution, serves to mobilize and allocate savings to the most productive activities that can increase productivity and national income (Mahran, 2012). Bank has a large portion of the financial sector in the world economy (Bokhari et al., 2012). In Indonesia's economy, the bank has a domi- nant role compared to other financial institutions (Bokhari, 2012). Moreover, the banking industry dominates the financial system in Indonesia. Banking market in Indonesia in the second half, 2014 was $78 \%$ of the total assets of financial institutions. Thus, a failure in the banking industry could destabilize the financial system and economy. Kashmir stated that the progress of banks in a country is a measure of the progress of the country (Kashmir, 2014).

Table 1: The Growth of LDR, Credit to Total Asset Ratio, and Portion of Credit Interest Income in Indonesia Banking Industry

\begin{tabular}{lcrrrrr}
\hline Items & Unit & \multicolumn{1}{c}{2010} & \multicolumn{1}{c}{2011} & \multicolumn{1}{c}{2012} & \multicolumn{1}{c}{2013} & \multicolumn{1}{c}{2014} \\
\hline LDR & $\%$ & 75,21 & 78,77 & 83,58 & 89,70 & 89,42 \\
Credit-to-Asset Ratio & $\%$ & 56,85 & 57,97 & 63,11 & 66,15 & 65,18 \\
Operational Income & Rp billion & 350.873 & 490.215 & 516.837 & 597.843 & 716.452 \\
Interest Income & Rp billion & 203.844 & 245.548 & 279.847 & 331.606 & 403.926 \\
Portion & $\%$ & 58,10 & 50,09 & 54,15 & 55,47 & 56,38 \\
\hline
\end{tabular}

Source: Indonesian Banking Statistics - Bank Indonesia, 2014 
The effectiveness of bank as an intermediary institution can be seen from the bank's ability to collect deposits in current accounts, savings and time deposits, which then channeled back in the form of credit. The performance of banking intermediation in Indonesia can be seen in Table 1. The composition of the bank's assets are dominated by the credit where the revenues are derived from loan interest income. Thus, the credit risk is one of the main risk exposures.

Credit Risk is the risk arising from default by a counterparty in meeting its obligations. Credit risk can be defined as a chance of debtor or counterparty to fail to meet its obligations (Frederick, 2012). It is a significant risk in the bank in line with the nature of its activities (Li et al., 2014), as well as the most important source of risk for commercial banks (Drehmann et al., 2008). Lending activity remains the bank's main business in the world, so the credit quality is considered as the main indicator of financial health and soundness of banks (Boahene et al., 2012).

Because credit risk is a major risk of a bank, the bank is required to identify, measure, monitor, control and provide enough capital for credit risk. In addition, banks are required to have a sufficient amount of capital, both to support its business expansion as well as a buffer to prevent an to absorb any unexpected losses (Raharjo et al., 2014).

Table 2: Rank of Risk Profile and Capital Adequacy Ratio (CAR)

\begin{tabular}{|c|c|}
\hline $\begin{array}{l}\text { Risk Profile } \\
\text { Rank }\end{array}$ & $\begin{array}{c}\text { Capital Adequacy Ratio } \\
\text { (CAR) }\end{array}$ \\
\hline 1 & $8 \%$ \\
\hline 2 & $9 \%$ but less than $10 \%$ \\
\hline 3 & $10 \%$ but less than $11 \%$ \\
\hline 4 or 5 & $11 \%$ but less than $14 \%$ \\
\hline
\end{tabular}

Bank uses capital to finance investments and decrease the likelihood of bankruptcy (Moussa, 2015) as well as to compete in global markets (Fitrianto et al., 2006). In line with this, Bank Indonesia, through Bank Indonesia Regulation No. 15/12/PBI/2013, December 12, 2013, had set the amount of capital a bank, tailored to the bank's risk profile. Banks with a high risk profile requires the support of a larger capital than banks with low risk profile in order to anticipate risks.

Commercial banks in Indonesia are also required to have additional capital as a buffer, in accordance with the criteria set by Bank Indonesia. Additional capital consists of capital conservation buffer, countercyclical buffer, and capital surcharge. Bank Indonesia set Capital Conservation Buffer at 2.5\% of risk weighted assets (ATMR), Countercyclical Buffer is set in range of $0 \%$ up to $2.5 \%$ of risk weighted assets (ATMR) and Capital Surcharge for Domestic Systematically Important Bank (D-SIB) is set in range of $1 \%$ to $2,5 \%$ of risk weighted assets (ATMR).

The banking industry in Indonesia currently consists of 119 conventional commercial bank with 19,948 office network. Bank Indonesia classifies banks into 6 groups, namely State Owned Banks Bank Persero (4 banks), Foreign Exchange Commercial Banks-Bank Umum Swasta Nasional Devisa (38 banks), Non-Foreign Exchange Commercial Banks-Bank Umum Swasta Nasional Non Devisa (29 banks), Regional Development Banks-Bank Pembangunan Daerah (26 banks), Joint Venture Banks-Bank Campuran (12 banks) and Foreign Owned Bank-Kantor Cabang Bank Asing (10 banks). During the study period, the CAR of the entire group of banks has exceeded the minimum CAR set $(8 \%)$ as Figure 1. This indicates that the banking industry has sufficient capital to support the growth in business volume and anticipate potential risks of its business activities.

Analysis of the factors affecting capital adequacy ratio (CAR) has been done by some previous researchers, both in Indonesia and in several other countries. Previous re- 
search revealed differences in the effect of credit risk on capital adequacy and profitability. The results of Shingjergji and Hyseni (2015) on the banking industry in Albania in the 2007-2014 period show that NPL negatively influences CAR, which contradicts the result of research conducted by Raharjo et al., (2014), which showed a significant positive correlation between CAR and NPL across group stated owned banks in Indonesia. The result of Dreca (2013) on 10 banks in Bosnia shows that ROA has a significant negative effect on CAR, which contradicts the result of Fitrianto et al. (2006) and Bateni et al. (2014) who found a significant positive relationship between ROA on CAR.
Based on the aforementioned various research results, and the consideration that the research in Indonesia is only done on a group of certain banks such as banks listed on the Jakarta Stock Exchange (Fitrianto et al., 2006), State Owned Banks (Raharjo et al., 2014) and 19 commercial banks (Nuviyanti, 2014) as well as the fact that capital adequacy is one parameter of bank health using the approach of RiskBased Bank Rating (RBBR), this study analyzed the effect of credit risk and profitability on the adequacy of capital in six groups of conventional commercial bank in Indonesia during the period 2010-2014.

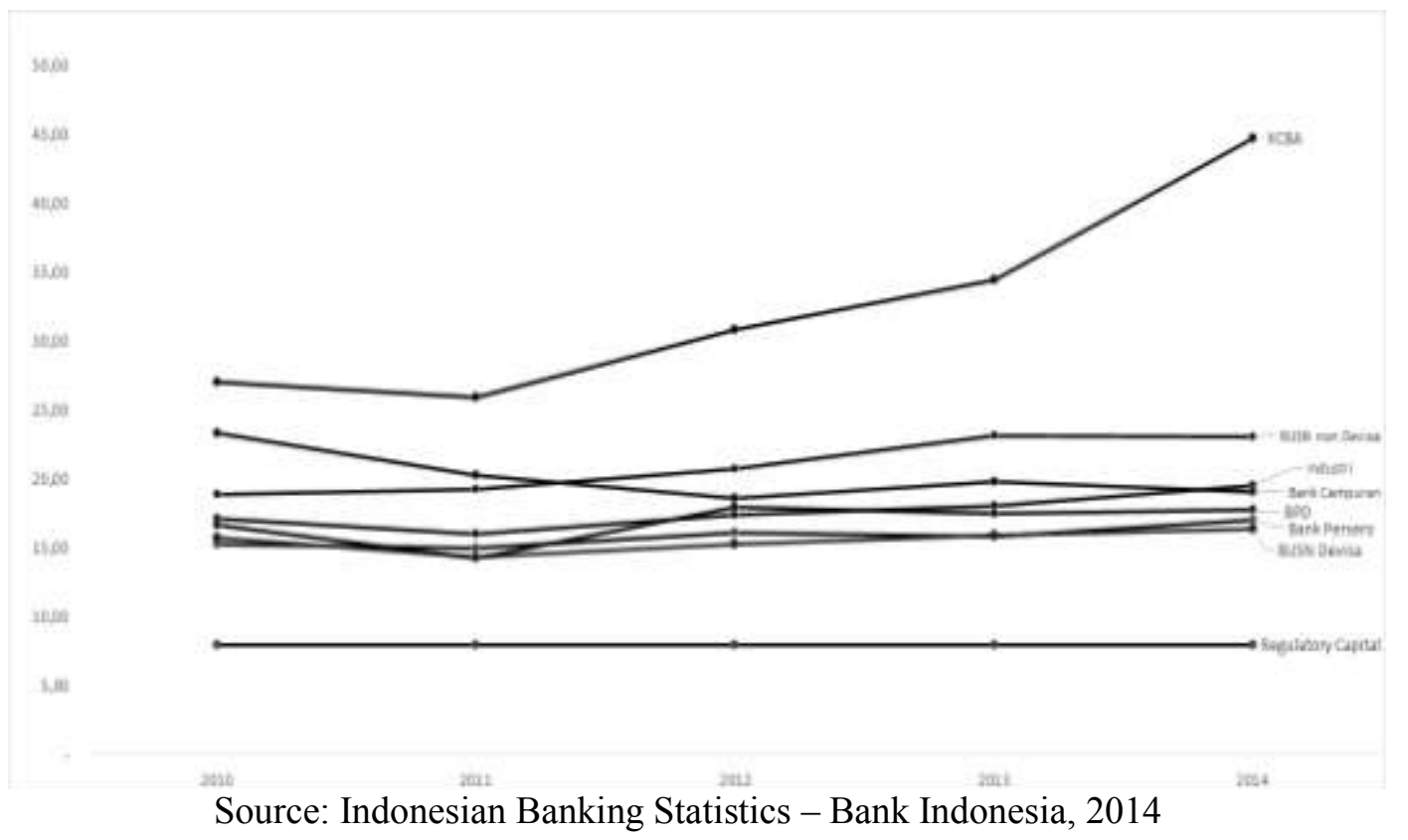

Figure 1: Growth of CAR during 2010-2014

Table 3: Analyzed Variables

\begin{tabular}{|c|c|c|c|}
\hline $\begin{array}{l}\text { Variable } \\
\text { Type }\end{array}$ & Variables Name & $\begin{array}{l}\text { Variable } \\
\text { Symbol }\end{array}$ & Variable Calculation \\
\hline $\begin{array}{l}\text { Bank's } \\
\text { level of risk }\end{array}$ & Capital Adequacy Ratio & CAR & (Capital/ATMR) x 100\% \\
\hline \multirow[t]{4}{*}{ Credit Risk } & Ratio of Loans to Total Assets & KTA & (Credit/Total Assets) x 100\% \\
\hline & Loan to Deposit Ratio & LDR & (Credit/Third Party Funds) x 100\% \\
\hline & Non Performing Loan & NPL & (Non performing loan/Total Credit) x $100 \%$ \\
\hline & Ratio of loan losses provision & CKPN & (CKPN/Total Credit) $\times 100 \%$ \\
\hline \multirow[t]{2}{*}{ Profitability } & $\begin{array}{l}\text { Operations Expenses to Opera- } \\
\text { tions Income }\end{array}$ & BOPO & (Operational Cost/Operational Income) x 100\% \\
\hline & Return on assets & ROA & $\begin{array}{l}\text { (Profit Before Tax /Average of Total Asset) } \mathrm{x} \\
100 \%\end{array}$ \\
\hline
\end{tabular}




\section{Methods}

This study extends previous research coverage by distinguishing the impact of credit risk on capital adequacy and profitability in each group of banks in Indonesia. The data used is monthly time series data ranges from January 2010 to December 2014 which is obtained from Banking Statistics Indonesia, Bank Indonesia. The data used are various financial ratios describing the condition and performance of the Indonesian banking industry, listed in Table 3 .

This study uses Error Correction Model (ECM) to model and analyze the data. This model can be used to determine the effect of short term and long term of the independent variables on the dependent variable. According to Engle and Granger (1987), ECM is a technique for correcting short-term imbalance towards long-term equilibrium to explain the relationship between independent variables and the dependent variable in the present and the past.

The data analysis begins with a stationary test to avoid spurious regression. The tests are performed using Augmented Dickey Fuller (ADF) test. Once the entire variables are stationary at the same rate, the next test is the cointegration test Engle and Granger. The test is intended to determine the possibility of long-term equilibrium relationship between independent and dependent variables. If the cointegration is evident, there would be a stable long term relationship across the variables. Meanwhile, to determine the short-term relationship, this paper uses an Engle-Granger error correction mechanism (ECM) model as follows:

$\Delta Y_{t}=\alpha_{0}+\alpha_{t} \Delta X_{t}+\alpha_{2} E C_{t}+\varepsilon_{t}$

$E C_{t}=Y_{t-1}-\beta_{0}-\beta_{1} X_{t-1}$,

$\Delta X_{t}=X_{t}-X_{t-1}$

where:

$\alpha=$ short run coefficients,

$\beta=$ long run coefficients,

$\alpha_{2}=$ non-equilibrium correction coefficient.

Non-equilibrium correction coefficient $\left(\alpha_{2}\right)$ is an absolute value that describes how quickly the time required to obtain the equilibrium value. Significant $\alpha_{2}$ indicates a short-term relationship between these variables.

The ECM model in this paper is as follows. First, the long run model for the $i^{\text {th }}$ bank is written as:

$$
\begin{aligned}
& C A R_{i t}=3_{0 i}+3_{1 j} K_{T A}+3_{2}: L D R \\
& +3_{3 i} N P L_{i t}+3{ }_{4 i} \text { CKPN }_{i t}+3_{5 i} B O \text { POO }_{i t} \\
& +3_{6 i}{ }^{2} O A_{i t}+i_{i t}
\end{aligned}
$$

Second, the short run model for the $i^{\text {th }}$ bank is written as:

$$
\begin{aligned}
& \Delta C A R_{i t}={ }_{0 i}+{ }_{1} \Delta \operatorname{KTA}_{i t}+{ }_{2}: \Delta L D R_{i t} \\
& \quad+{ }_{3 i} \Delta N P L_{i t}+{ }_{4 i} \Delta C K P N_{i t}+{ }_{{ }_{5}} \Delta B O P O_{i t} \\
& \quad+{ }_{6 i} \Delta R O A_{i t}+{ }_{7 i} \Delta E C T_{i(t-1)}+{ }_{i t}
\end{aligned}
$$

\section{Results and Discussion}

\section{Stationarity test}

Stationarity test results showed that all variables are not stationary at level. The test is then carried out for the first difference of the variables. The test results show that all the probability are less than $5 \%$, indicating they are stationary at the first difference (see Table 4).

\section{Co-integration test}

Cointegration test results showed that all the residuals of the long-term equation are stationary at level, reflecting the cointegration or long-term equilibrium. Therefore, we have resons to construct the ECM model, with the results listed in Table 5.

\section{Short run model}

The estimation of short-term equations in this study performed on each group of banks. The results are presented in Table 7.

The results showed that the variables of credit risk (KTA, LDR, NPLs and CKPN) and variable of profitability performance (BOPO and ROA) altogether influence the capital adequacy ratio (CAR) in each group of banks during the period 2010-2014. 
Table 4: Unit Root Test Result

\begin{tabular}{|c|c|c|c|c|c|c|c|}
\hline Variable & Uji difference & $\begin{array}{l}\text { Stated } \\
\text { Own } \\
\text { Bank }\end{array}$ & $\begin{array}{l}\text { Foreign } \\
\text { Exchange } \\
\text { Commer } \\
\text { cial Banks }\end{array}$ & $\begin{array}{l}\text { Non-Foreign } \\
\text { Exchange } \\
\text { Commer cial } \\
\text { Banks }\end{array}$ & $\begin{array}{c}\text { Regional } \\
\text { Develop } \\
\text { ment } \\
\text { Banks }\end{array}$ & $\begin{array}{c}\text { Joint } \\
\text { Venture } \\
\text { Banks }\end{array}$ & $\begin{array}{c}\text { Foreign } \\
\text { Owned } \\
\text { Banks }\end{array}$ \\
\hline \multirow{6}{*}{ CAR } & ADF in level & 0,1035 & 0,6139 & 0,5572 & 0,4979 & 0,5483 & 0,3201 \\
\hline & $\mathrm{ADF}$ in first difference & 0,0000 & 0,0000 & 0,0000 & 0,0000 & 0,0000 & 0,0000 \\
\hline & $\begin{array}{l}\text { Absolute critical } \\
\text { statistic of McKinnon }\end{array}$ & & & & & & \\
\hline & $1 \%$ level & 3,5461 & 2,6047 & 3,5527 & 2,6047 & 4,1213 & 4,1213 \\
\hline & $5 \%$ level & 2,9117 & 1,9464 & 2,9145 & 1,9464 & 3,4878 & 3,4878 \\
\hline & $10 \%$ level & 2,5936 & 1,6132 & 2,5950 & 1,6132 & 3,1723 & 3,1723 \\
\hline \multirow{6}{*}{ KTA } & p-value in level & 0,3629 & 0,6704 & 0,1032 & 0,3235 & 0,1785 & 0,1540 \\
\hline & $\mathrm{ADF}$ in first difference & 0,0000 & 0,0000 & 0,0000 & 0,0000 & 0,0000 & 0,0000 \\
\hline & $\begin{array}{l}\text { Absolute critical } \\
\text { statistic of McKinnon }\end{array}$ & & & & & & \\
\hline & $1 \%$ level & 4,1213 & 4,1213 & 4,1213 & 3,5461 & 4,1213 & 4,1213 \\
\hline & $5 \%$ level & 3,4878 & 3,4878 & 3,4878 & 2,9117 & 3,4878 & 3,4878 \\
\hline & $10 \%$ level & 3,1723 & 3,1723 & 3,1723 & 2,5936 & 3,1723 & 3,1723 \\
\hline \multirow{6}{*}{ LDR } & p-value ada level & 0,1061 & 0,4505 & 0,1543 & 0,1774 & 0,2754 & 0,2272 \\
\hline & $\mathrm{ADF}$ in first difference & 0,0000 & 0,0000 & 0,0000 & 0,0000 & 0,0000 & 0,0000 \\
\hline & $\begin{array}{l}\text { Absolute critical } \\
\text { statistic of McKinnon }\end{array}$ & & & & & & \\
\hline & $1 \%$ level & 4,1213 & 4,1213 & 3,5461 & 3,5461 & 3,5461 & 4,1213 \\
\hline & $5 \%$ level & 3,4878 & 3,4878 & 2,9117 & 2,9117 & 2,9117 & 3,4878 \\
\hline & $10 \%$ level & 3,1723 & 3,1723 & 2,5936 & 2,5936 & 2,5936 & 3,1723 \\
\hline \multirow{6}{*}{ NPL } & p-value in level & 0,6236 & 0,9530 & 0,3817 & 0,4398 & 0,9994 & 0,0647 \\
\hline & ADF in first difference & 0,0000 & 0,0000 & 0,0000 & 0,0000 & 0,0000 & 0,0000 \\
\hline & $\begin{array}{l}\text { Absolute critical } \\
\text { statistic of McKinnon }\end{array}$ & & & & & & \\
\hline & $1 \%$ level & 4,1273 & 4,1213 & 3,5461 & 4,1213 & 4,1213 & 4,1213 \\
\hline & $5 \%$ level & 3,4907 & 3,4878 & 2,9117 & 3,4878 & 3,4878 & 3,4878 \\
\hline & $10 \%$ level & 3,1739 & 3,1723 & 2,5936 & 3,1723 & 3,1723 & 3,1723 \\
\hline \multirow{5}{*}{ CKPN } & $\mathrm{p}$-value in level & 0,7678 & 0,4278 & 0,6460 & 0,5618 & 0,7673 & 0,0122 \\
\hline & ADF in first difference & 0,0000 & 0.000 & 0,0000 & 0,0000 & 0,0000 & 0,0000 \\
\hline & Absolute critical & & & & & & \\
\hline & $1 \%$ level & 3,5504 & 4,1213 & 4,1213 & 35464 & 41213 & 26130 \\
\hline & $5 \%$ level & 2,9135 & 3,4878 & 3,4878 & 2,9117 & 3,4878 & 1,9477 \\
\hline \multirow{6}{*}{ BOPO } & p-value in level & 0,4374 & 0,1595 & 0,1140 & 0,0439 & 0,1593 & 0,2940 \\
\hline & ADF in first difference & 0,0000 & 0,0000 & 0,0000 & 0,0000 & 0,0000 & 0,0000 \\
\hline & $\begin{array}{l}\text { Absolute critical } \\
\text { statistic of McKinnon }\end{array}$ & & & & & & \\
\hline & $1 \%$ level & 2,6062 & 4,1243 & 2,6047 & 2,6054 & 3,5461 & 4,1213 \\
\hline & $5 \%$ level & 1,9467 & 3,4892 & 1,9464 & 1,9465 & 2,9117 & 3,4878 \\
\hline & $10 \%$ level & 1,6131 & 3,1723 & 1,6132 & 1,6131 & 2,5936 & 3,1723 \\
\hline \multirow{6}{*}{ ROA } & p-value in level & 0,1215 & 0,1649 & 0,2360 & 0,0439 & 0,3915 & 0,3692 \\
\hline & $\mathrm{ADF}$ in first difference & 0,0000 & 0,0000 & 0,0000 & 0,0000 & 0,0000 & 0,0000 \\
\hline & $\begin{array}{l}\text { Absolute critical } \\
\text { statistic of McKinnon }\end{array}$ & & & & & & \\
\hline & $1 \%$ level & 4,1213 & 3,5461 & 3,5461 & 2,6054 & 2,6047 & \\
\hline & $5 \%$ level & 3,4878 & 2,9117 & 2,9117 & 1,9465 & 1,9464 & \\
\hline & $10 \%$ level & 3,1723 & 2,5936 & 2,5936 & 1,6131 & 1,6132 & \\
\hline
\end{tabular}


Table 5: Co-integration Test Results (Residual Stationarity)

\begin{tabular}{|c|c|c|c|c|c|c|c|}
\hline Variable & Uji difference & $\begin{array}{c}\text { Stated } \\
\text { Own Bank }\end{array}$ & $\begin{array}{c}\text { Foreign } \\
\text { Exchange } \\
\text { Commer } \\
\text { cial Banks }\end{array}$ & $\begin{array}{c}\text { Non- } \\
\text { Foreign } \\
\text { Exchange } \\
\text { Commer } \\
\text { cial Banks }\end{array}$ & $\begin{array}{c}\text { Regional } \\
\text { Develop } \\
\text { ment } \\
\text { Banks }\end{array}$ & $\begin{array}{l}\text { Joint Venture } \\
\text { Bank }\end{array}$ & $\begin{array}{l}\text { Foreign } \\
\text { Owned } \\
\text { Banks }\end{array}$ \\
\hline \multirow{6}{*}{$\begin{array}{c}\text { Residual } \\
\text { (ECT) }\end{array}$} & p-value in level & 0,0000 & 0,0001 & 0,0000 & 0,0012 & 0,0277 & 0,0003 \\
\hline & \multicolumn{7}{|c|}{ McKinnon critical value: } \\
\hline & $1 \%$ level & 3,5482 & 3,5461 & 3,5461 & 3,5461 & 2,6047 & 3,5461 \\
\hline & $5 \%$ level & 2,9126 & 2,9117 & 2,9117 & 2,9117 & 1,9464 & 2,9117 \\
\hline & $10 \%$ level & 2,5940 & 2,5935 & 2,5935 & 2,5935 & 1,6132 & 2,5935 \\
\hline & Conclusion & stationary & stationary & stationary & stationary & stationary & stationary \\
\hline
\end{tabular}

Table 6: Long Run Estimation Results

\begin{tabular}{lrrrrrr}
\hline Variable & $\begin{array}{c}\text { Stated Own } \\
\text { Bank }\end{array}$ & $\begin{array}{c}\text { Foreign } \\
\text { Exchange } \\
\text { Commercial } \\
\text { Banks }\end{array}$ & $\begin{array}{c}\text { Non-Foreign } \\
\text { Exchange } \\
\text { Commercial } \\
\text { Banks }\end{array}$ & $\begin{array}{c}\text { Regional } \\
\text { Development } \\
\text { Banks }\end{array}$ & $\begin{array}{c}\text { Joint } \\
\text { Venture } \\
\text { Bank }\end{array}$ & $\begin{array}{c}\text { Foreign } \\
\text { Owned } \\
\text { Banks }\end{array}$ \\
\hline C & 22,4710 & 9,7270 & 8,9216 & 15,1705 & 25,9974 & $-30,2635$ \\
KTA & $-0,9011$ & 0,2731 & 0,0290 & $-0,2750$ & $-0,2596$ & $-0,0329$ \\
LDR & 0,5979 & $-0,1521$ & 0,1336 & 0,1710 & 0,0246 & 0,3779 \\
NPL & 0,5085 & 0,5291 & 1,7851 & 2,8985 & 1,3828 & 0,4768 \\
CKPN & $-0,9239$ & 0,2420 & $-2,5378$ & $-3,4317$ & 1,2536 & 0,4484 \\
BOPO & 0,0117 & 0,0442 & 0,0174 & $-0,0004$ & 0,0356 & 0,2010 \\
ROA & 1,0197 & $-1,5166$ & $-0,1525$ & 1,7851 & 0,9032 & 0,9274 \\
R2 adj & 0,6205 & 0,4634 & 0,5357 & 0,3362 & 0,7149 & 0,8621 \\
\hline
\end{tabular}

Table 7: Long Run Estimation Results (ECM Estimation Results)

\begin{tabular}{lrrrrrr}
\hline Variable & $\begin{array}{c}\text { Stated Own } \\
\text { Bank }\end{array}$ & $\begin{array}{c}\text { Foreign } \\
\text { Exchange } \\
\text { Commercial } \\
\text { Banks }\end{array}$ & $\begin{array}{c}\text { Non-Foreign } \\
\text { Exchange } \\
\text { Commercial } \\
\text { Banks }\end{array}$ & $\begin{array}{c}\text { Regional } \\
\text { Development } \\
\text { Banks }\end{array}$ & $\begin{array}{c}\text { Joint } \\
\text { Venture } \\
\text { Banks }\end{array}$ & \multicolumn{1}{c}{$\begin{array}{c}\text { Foreign } \\
\text { Owned } \\
\text { Banks }\end{array}$} \\
\hline C & 0,0185 & 0,0248 & 0,1170 & $-0,0019$ & $-0,0625$ & 0,3287 \\
D(KTA) & $\left.-0,6325^{*}\right)$ & 0,1474 & 0,0687 & $-0,0478$ & 0,0513 & $-0,0309$ \\
D(LDR) & $\left.0,4847^{*}\right)$ & $-0,0771$ & 0,0620 & $-0,0011$ & $-0,0297$ & $-0,0214$ \\
D(NPL) & 0,5444 & $1,5744 *)$ & 1,4499 & 1,8662 & 0,1028 & 0,6824 \\
D(CKPN) & 0,0956 & $-0,0463$ & 1,2526 & $-0,6073$ & $\left.2,0771^{*}\right)$ & $\left.0,3534^{*}\right)$ \\
D(BOPO) & $-0,0005$ & 0,0350 & 0,1029 & 0,0458 & 0,0419 & 0,0127 \\
D(ROA) & 0,0253 & $-0,9902$ & $\left.1,5059^{*}\right)$ & $\left.1,2064^{*}\right)$ & 0,0604 & 0,0257 \\
ECT & $-0,6105$ & $-0,5756$ & $-0,7163$ & $-0,4881$ & $-0,2013$ & $-0,2696$ \\
R2 adj & 0,3965 & 0,4251 & 0,3932 & 0,3520 & 0,1480 & 0,1568 \\
\hline
\end{tabular}

*) signifikan at $\alpha=5 \%$

Partially, in the short term, all the variables significantly influence CAR except BOPO. Table 1 shows that the share of loan interest income to operating income decreased although the portion of loans to total assets increased. In other words, there are non-operating income that contribute to the performance of profitability that is an organic source of funds such as rental income, gain on sale of fixed assets, and gains on foreign exchange transactions as well as additional capital through a rights issue explicitly (tier 1) and the issuance of securities of subordinated (tier 2) as nonorganic source to strenghten capital funds of the banking industry. 
Table 8: Influence of Credit Risk and Profitability on Capital Adequacy

\begin{tabular}{lcccccc}
\hline Variable & $\begin{array}{c}\text { Stated Own } \\
\text { Bank }\end{array}$ & $\begin{array}{c}\text { Foreign } \\
\text { Exchange } \\
\text { Commercial } \\
\text { Banks }\end{array}$ & $\begin{array}{c}\text { Non-Foreign } \\
\text { Exchange } \\
\text { Commercial } \\
\text { Banks }\end{array}$ & $\begin{array}{c}\text { Regional } \\
\text { Development } \\
\text { Banks }\end{array}$ & $\begin{array}{c}\text { Joint } \\
\text { Venture } \\
\text { Banks }\end{array}$ & $\begin{array}{c}\text { Foreign } \\
\text { Owned } \\
\text { Banks }\end{array}$ \\
\hline KTA & ns & - & - & - & - & - \\
LDR & ps & - & - & - & - & - \\
NPL & - & ps & - & - & - & - \\
CKPN & - & - & - & - & ps & ps \\
BOPO & - & - & - & - & - & - \\
ROA & - & - & ps & ps & - & - \\
ECT $(-1)$ & $-0,6105$ & $-0,5756$ & $-0,7163$ & $-0,4881$ & $-0,2013$ & $-0,696$ \\
\hline NO
\end{tabular}

Notes: $\left.{ }^{*}\right)$ ns: negative significant; $\left.{ }^{* *}\right)$ ps: positive significant

The results of short run model estimation indicate that the variables that significantly influence the CAR are KTA and LDR (Sated Owend Bank), NPL (Foreign Exchange Commercial Banks), CKPN (Joint Venture Bank and Foreign Owned) and ROA (Non-Foreign Exchange Commercial Banks and Regional Development Banks). The different types of variables that significantly influence the capital adequacy ratio (CAR) is influenced by the characteristics and complexity of each group of banks. The estimation results of shortterm model in each bank group has Error Correction Term (ECT) with a negative sign. This figure reflects the direction towards the long-term balance. The adjustment process lasted less than one year.

\section{Conclusion}

Lending activity is the main business of a bank making the loan interest income as core income. As the result, the credit risk becomes a major risk in the banking industry. The test results by using ECM shows that in the short terms, variables of credit risk (KTA, LDR, NPL and CKPN) and variables of profitability (BOPO and ROA), jointly significantly affect the adequacy capital (CAR). Partially, variables that significantly influence the CAR are depend on the characteristics and complexity of the bank group. The results of this study indi- cate that the pace towards the long-term balance in general is less than one year.

The credit risk has a potential impact on capital adequacy ratio (CAR) so that the bank needs good of risk management to identification, measurement, monitoring, control and mitigate of those risks. This is in line with Bank Indonesia Regulation (PBI) No. 5/8/PBI/2003 dated May 19, 2003 which was amended by Regulation No. 11/25/PBI/2009 dated July 1, 2009 on the Application of Risk Management for Commercial Banks. Banks with a high risk profile requires the support of a larger capital than banks with low risk profile do.

The quality of credit risk management is the basis for determining the credit quality based solely on the accuracy of pay. Credit risk is one of the basic assessment in determining the risk profile of the bank as stipulated in Bank Indonesia Regulation No. 13/1/PBI/2011 dated January 15, 2011. In anticipation of the effect of credit risk, banks can improve the quality of risk management, giving credit to the basic principles and the precautionary principle, increasing reserves, and strengthening the capital structure.

During the span of the study period, the banking industry has a capital ratio exceeding $8 \%$, which is the regulatory capital. This shows that the bank has set aside to anticipate external impacts, in addition to implementing PBI No. 15/12 / PBI / 2013 
concerning the Minimum Capital Requirement for Commercial Banks. The regulations require banks to increase capital formation as a buffer in the form of Capital Conservation Buffer, and Countercyclical Buffer. In addition, the Bank with the potential systemic risk is required to establish additional capital in the form of Capital Surcharge.

\section{References}

Bank Indonesia (2009), Bank Indonesia Regulation (PBI) Nomor 11/25/PBI/2009 dated July 1, 2009 regarding Amendment to PBI Nomor 5/8/PBI/2003 dated May 19, 2003 concerning The Implementation Of Risk Management for Commercial Bank, State Gazette of The Republic of Indonesia Year 2009 Number 103 DPNP.

Bank Indonesia (2011), Bank Indonesia Regulation (PBI) Nomor 13/1/PBI/2011 dated January 15, 2011 concerning Bank Soundness Rating Assessment for Commercial Bank, State Gazette of The Republic of Indonesia Year 2012 Number 1 DPNP.

Bank Indonesia (2013), Bank Indonesia Regulation (PBI) Nomor 15/12/PBI/2013 dated December 12, 2013 concerning Minimum Capital Adequacy Requirement for Commercial Bank, State Gazette of The Republic of Indonesia Year 2013 Number 223 DPNP.

Bank Indonesia (2014), Indonesian Banking Statistic, Bank Indonesia.

Bateni, L., Vakilifard, H., and Asghari (2014), "The Influential Factors on Capital Adequacy Ratio in Irians Banks," International Journal and Finance, 6(11), 108-116.

Boahene, S.H., Dasah, J., and Agyei, S.K. (2012), "Credit Risk and Profitabili- ty of Selected Bank in Ghana," Research Journal of Finance and Accounting, 3(7), 6-14.

Bokhari, I.H., Ali, S.M., and Sultan, K. (2012), "Determinant of Capital Adequacy Ratio in Banking Sector: An Empirical Analysis from Pakistan," Academy of Comtempory Research Journal, 7(1), 1-9.

Dreca, N. (2013), "Determinants of Capital Adequacy Ratio In Selected BosnianBanks," Dumlupınar Üniversitesi Sosyal Bilimler Dergisi EYİ 2013 Özel Sayıs1, 149-162.

Drehmann, M., Sorensen, S., and Stringa, M., (2008), "The Integrated Impact of Credit and Interest Rate Risk on Banks: An Economic Value and Capital Adequacy Perspective," Working Paper No.339, Bank of England.

Engle, R.F. and Granger, C.W.J. (1987), "Co-Integration and Error Correction: Representation, Estimation, and Testing," Econometrica, 55(2), 251-276.

Fitrianto, H., and Mawardi, W. (2006), "Analysis of Asset Quality, Liquidity, Profitability and Efficiency of the Capital Adequacy Ratio Banks Listed in Bursa Efek Jakarta," Jurnal Studi Manajemen \& Organisasi, 3(1), 1-11.

Fredrick O. (2012),"The Impact of Credit Risk Management on Financial Performance ofCommercial Banks in Kenya," DBA Africa Management Review, 3(3), 22-37.

Fungáčová, Z., and Poghosyan, T. (2014), "Determinants of Bank Interest Margins in Russia: Does Bank Ownership Matter?" BOFIT Discussion Papers 22.

Kasmir (2014), Basic Fundamentals Of Banking, Jakarta, PT. Raja Grafindo. 
Li F., and Zou, Y. (2014), "The Impact of Credit Risk Management on Profitability of Commercial Banks: A Study of Europe", Thesis. Swedia: Umea University.

Mahran, H.A. (2012), "Financial Intermediation and Economic Growth in Saudi Arabia: An Empirical Analysis1968-2010," Journal Modern Economy, 3, 626-640.

Moussa, M.A.B. (2015), ’The Relationship between Capital and Bank Risk: Evidence from Tunisia," International Journal of Economics and Finance, 7(4), 223-232.

Nuviyanti, A.H. (2014), "Determinants of Capital Adequacy Ratio (CAR) in 28 Commercial Banks (Case Study:
Period 2008-2013)," Journal of Business and Management, 3(7), 752-764.

Raharjo, P.G., Hakim, D.B., Manurung A.H., and Maulana T.N.A. (2014), "Determinant of Capital Ratio: A Panel Data Analysis on State Own Banks in Indonesia," Buletin Ekonomi Moneter dan Perbankan, 16(4), 395-414.

Shingjergji, A. and Hyseni, M. (2015), "The Determinant of Capital Adequacy ratio in The Albanian banking System during 2007-2014," International Journal of Economic, Commere and Management, 3(1), 1-10. 